\title{
Screening for infectious diseases in newly arrived asymptomatic immigrants in southern Italy
}

Gaetano Scotto, ${ }^{1}$ Vincenzina Fazio, ${ }^{2}$ Lorenzo Lo Muzio ${ }^{3}$ and Nicola Coppola ${ }^{4}$

${ }^{1}$ Faculty of Medicine and Surgery; ${ }^{3}$ Department of Clinical and Experimental Medicine, University of Foggia, Foggia, Italy (Correspondence to: Gaetano Scotto: gaetano.scotto@unifg.it). ${ }^{2}$ Clinical Chemistry Laboratory, Virology Unit, Foggia Hospital, Foggia, Italy. ${ }^{4}$ Department of Mental Health and Public Medicine, Infectious Diseases Section, Second University of Naples, Naples, Italy.

\begin{abstract}
Background: Screenings for infectious diseases in asymptomatic immigrants currently takes place when receiving new arrivals.

Aims: We describe the frequency of infections in a cohort of newly arrived asymptomatic immigrants in Southern Italy.

Methods: We studied a cohort of 238 Sub-Saharan African and Asian men hosted at a reception centre (CARA) in Foggia between January and December 2015. The tuberculin skin test for diagnosis of latent tuberculosis infection (LTBI) and serology/virology testing for HBV, HCV, HIV were performed.

Results: From this cohort, 205 individuals agreed to be tested for serological/virological markers only, while 82 agreed to be tested for LTBI only; 49 people agreed to have both tests. Among those tested for virological markers, 23/205 (11.2\%) were HBsAg positive; $12 / 23$ (52.2\%) individuals had chronic active hepatitis; 77/205 (37.6\%) individuals had only anti-HBc positivity. HCV infection was present in 8/205 (3.9\%) individuals, and chronic HCV infection, was diagnosed in only two people. Only $2 / 205(1.0 \%)$ individuals presented with anti-HIV and HIV-RNA positivity. We found LTBI in $29.6 \%$ of TB-tested individuals.
\end{abstract}

Conclusions: Asymptomatic immigrants are at increased risk for some infections, mainly HBV and tuberculosis.

Keywords: epidemiology, infectious diseases, LTBI, newly arrived immigrants, Italy

Citation: Scotto G; Fazio V; Lo Muzio L; Coppola N. Screening for infectious diseases in newly arrived asymptomatic immigrants in southern Italy. East Mediterr Health J. 2019;25(4):246-253. https://doi.org/10.26719/emhj.18.035

Received: 15/02/17; accepted: 11/10/17

Copyright (c) World Health Organization (WHO) 2019. Some rights reserved. This work is available under the CC BY-NC-SA 3.0 IGO license (https:// creativecommons.org/licenses/by-nc-sa/3.o/igo).

\section{Introduction}

The last 20 years has seen considerable migration from low- and middle-income countries to high-income nations, primarily the United States of America and Western Europe. On 1 January 2016, the number of people living in a European Union (EU) member state who were citizens of nonmember countries was 20.7 million. In Italy this represented about 4 million people or $6.7 \%$ of the population (1). This remarkable increase in people whose living conditions are often considerably disadvantaged has sometimes led to problems, not only of a socioeconomic and security nature but also in regard to sanitation and health. In fact, while most tropical diseases are absent or appear sporadically in Italy (2,3), it was observed that the prevalence/incidence of other pathologies such as $\mathrm{HBV} / \mathrm{HCV} / \mathrm{HIV} / \mathrm{TB}$ have changed their epidemiology over the years, in accord with the immigration phenomenon. Some infections have been directly imported, in both latent and active forms. Others have been contracted by immigrants because of living conditions/habits, with an increase in some infectious diseases such as HIV (3), TB (4) and viral hepatitis $(5,6)$ and sometimes co-infections (6).

Southern Italy has been, and still is, a major destination for illegal immigration (African, Middle Eastern and Asian) from the North African coast (7). On arrival, the immigrants are hosted in reception centres (CARA), which are distributed in various parts of Italy. Most are young and healthy individuals, but they are often considered a source of certain infectious diseases such as Ebola, SARS etc., occasionally resulting in unjustified prejudice because of their geographic origin, ethnicity, health conditions at the departure point, and the migratory route $(8-10)$. Therefore, the identification and treatment of any imported asymptomatic infections could reduce their incidence/prevalence and modify their outcome. This can have a significant clinical and psychological impact, both for the individual affected and for public health (10).

The health service for immigrants in Italy, particularly for clandestines, is not adequate and most assistance is currently provided by religious or lay volunteer groups. Only recently have hospitals and local health services initiated the creation of outpatient clinics for immigrants, including soliciting the help of cultural workers and interpreters (10). In such a challenging scenario, the team of volunteer doctors participating in this study have been screening immigrants hosted in the CARA in Foggia (Apulia, Southern Italy) for infectious diseases for several years.

The aim of this research, conducted in 2015, was to determine the possible presence of $\mathrm{HIV} / \mathrm{HBV} / \mathrm{HCV} / \mathrm{TB}$ infections in a cohort of asymptomatic immigrants who 
were temporarily guests at the CARA in Foggia, and to measure the burden of latent or active infections which are potentially harmful for the individuals' health and transmissible to the community.

\section{Methods}

\section{Participants and tests}

Between January and December 2015 we screened 238 asymptomatic immigrants for HIV/HBV/HCV/TB. Before screening, all guests at the CARA (728 persons) were informed about the purpose of the study and invited to participate. Subsequent recruitment was on a voluntary basis; the recruitment of minors was mediated by tutors. The study was reviewed and approved by the general manager and the medical director of the CARA, and written informed consent, provided in 4 languages (English, French, Arabic and Italian), was obtained from each participant. All study procedures conformed with the Helsinki Declaration (1975, amended 2008).

At the time of enrolment, all participants were interviewed using a questionnaire to obtain demographic and clinical information. None of the screened participants reported previous exposure to infectious diseases, nor vaccination for hepatitis $B$, nor vaccination or anti-tuberculosis prophylaxis. All enlisted participants went through complete clinical tests and, if necessary, we proceeded with further diagnostic tests and treatment. In addition, we implemented a strategy to prevent any transmission to other immigrants and indigenous populations who lived in close contact with infected persons. Diagnoses of infections were made using standard commercial tests. The health examination performed for all asymptomatic immigrants was based on systematic screening that included serological and virological examination for selected infections: HIV, HBV, HCV virus, and a check for possible latent tuberculosis infection (LTBI) using the tuberculin skin test (TST).

\section{Statistical analysis}

Categorical data are presented as absolute numbers and proportions. Continuous variables were summarized as mean and standard deviation (SD), and categorical variables as absolute and relative frequencies. Differences in the mean values for continuous variables (age, HBV genotypes) were evaluated by the Student t-test for independent samples. The Chi-squared test was applied to compare categorical variables (ethnicity, $\mathrm{HIV} / \mathrm{HCV}$ antibodies, HBV markers and TST positivity); $\mathrm{P}<0.05$ was considered statistically significant.

\section{Results}

\section{Demographic characteristics}

One hundred and thirty-two (132) of the 238 participants enrolled in the study (55.5\%) came from Sub-Saharan African countries (54.2\% from East Africa, 35.9\% from West Africa, 10.8\% from Central Africa) and 106 (44.5\%) were from Asia, mainly from the Indian subcontinent and Pakistan. The mean age was 25.1 (SD 5.7; range 13-40) years. All of the participants were men since the population of the CARA was exclusively male. Subjects had been in Italy for a mean period of 36 days (range 7-118 days) (Table 1). Among the study population, 205/238 immigrants (86.1\%; 111 Africans, 94 Asians) agreed to be tested only for serological/virological markers (HBsAg/anti-HBc, anti-HCV, anti-HIV) and 82 individuals agreed to be tested for TB (TST). Only 49 participants agreed to have both tests (Table 2).

\section{HBV infection}

Among the individuals we tested, 23/205 (11.2\%) were HBsAg positive: $17 / 23$ (73.9\%) Africans and 6/23 (26.1\%) Asians $(P=0.03) ; 16$ patients were anti-HBe positive while 7 (2 of whom were Asians) presented with HBV-wildtype (HBsAg/HBeAg positive). Chronic active HBV (CHB) infection, with HBV-DNA detectable using real-time polymerase chain reaction testing, was present in 12/23 (10 Africans and 2 Asians, $P=0.03 ; 52.2 \%$ ) HBsAg positive individuals (mean level 1374231 copies/mL, range

\begin{tabular}{|c|c|c|c|c|}
\hline Geographical origin & Patients & $\begin{array}{l}\text { Screened for HBV, } \\
\text { HCV and HIV }\end{array}$ & Screened for TB & $\begin{array}{l}\text { Screened for HBV, } \\
\text { HCV, HIV and TB }\end{array}$ \\
\hline Africa & 132 & 111 & 56 & 27 \\
\hline East Africa & 71 & 59 & 28 & 16 \\
\hline West Africa & 47 & 41 & 14 & 6 \\
\hline Central Africa & 14 & 11 & 7 & 7 \\
\hline Asia & 106 & 94 & 26 & 22 \\
\hline Pakistan & 43 & 41 & 17 & 14 \\
\hline Bangladesh & 26 & 21 & 3 & 3 \\
\hline India & 16 & 12 & 3 & 3 \\
\hline Other countries & 21 & 20 & 3 & 3 \\
\hline Total & 238 & 205 & 82 & 49 \\
\hline
\end{tabular}


74 651-13 875 247). Nine CHB patients presented e-minus mutant virus and 3 had HBV-wildtype virus. Genotype distribution among all CHB/HBV-DNA positive patients was: $5 / 12$ genotype $E$ (51.7\%), 3/12 genotype $A$ (25.0\%), 2/12 genotype $\mathrm{D}(16.7 \%), 1 / 12$ genotype $\mathrm{B}(8.3 \%)$, and $1 / 12$ genotype C (8.3\%). Genotypes E, A and D were associated with the African subgroup while genotypes $C$ and $B$ were associated with the Asian subgroup.

A significant statistical difference was observed between genotype $E$ and the other genotypes $(P=0.02)$; the difference in prevalence between genotypes $A, B, C$ and $D$ $(P=0.08)$ was modest. We found 77 individuals $(37.6 \%)$ had anti-HBc positivity (OBI), a bio-marker of previous HBV infection. The prevalence among sub-Saharan Africans was $66.2 \%(51 / 77)$, compared with $33.8 \%$ (26/77) among Asians $(P=0.03)$. All participants denied having previous $\mathrm{HBV}$ vaccinations in their country of origin. Five out of 77 participants (with slight hypertransaminasaemia) had HBV-BNA positivity with a low viral load (mean level 1275 copies/mL, range 471-5743); genotyping was not performed.

\section{HCV infection}

Infection with $\mathrm{HCV}$ was present in 8/205 individuals (3.9\%): $3 / 8(37.5 \%)$ were Africans and 5/8 (62.5\%) were Asians $(P=0.02)$. Chronic HCV infection, with the presence of HCV-RNA detectable by real-time polymerase chain reaction testing, was diagnosed in only 3 Asian patients; HCV genotyping was performed in these individuals: 2 presented with genotype 1 a and 1 with genotype 3 .

\section{HIV infection}

Only 2/205 (1.0\%) individuals presented anti-HIV antibodies, and subsequently we were able to detect HIV-RNA; 1 was African and the other was Asian. The HIV-positive immigrants were not aware of their serologic status before their arrival or, at least, they did not acknowledge sero-positivity for HIV. Neither of the 2 patients showed an AIDS-defining disease or other clinical symptoms at the time of screening; only 1 patient developed pulmonary active tuberculosis during the first month of follow-up.

\begin{tabular}{|c|c|c|c|c|c|c|c|c|c|c|c|}
\hline \multirow{2}{*}{$\begin{array}{l}\text { Epidemiological and } \\
\text { clinic features }\end{array}$} & \multirow[t]{2}{*}{ Total No. } & \multicolumn{9}{|c|}{ Origin } & \multirow[t]{2}{*}{ P-value ${ }^{\text {a }}$} \\
\hline & & $\begin{array}{l}\text { Africa } \\
\text { (Af) }\end{array}$ & $\begin{array}{c}\text { East } \\
\text { Africa }\end{array}$ & $\begin{array}{l}\text { West } \\
\text { Africa }\end{array}$ & $\begin{array}{l}\text { Central } \\
\text { Africa }\end{array}$ & Asia (As) & Pakistan & $\begin{array}{c}\text { Bangla- } \\
\text { desh }\end{array}$ & India & $\begin{array}{l}\text { Other } \\
\text { coun- } \\
\text { tries }\end{array}$ & \\
\hline $\mathrm{HBsAg}+$ & 23 & 17 & 6 & 4 & 7 & 6 & 2 & 2 & 1 & 1 & $0.03^{b}$ \\
\hline $\mathrm{HBeAg}+$ & 7 & 3 & 2 & 1 & & 4 & 1 & 1 & 1 & 1 & \\
\hline HBV-DNA+, HBsAg+, OBI & 17 & 13 & 4 & 5 & 4 & 4 & & 2 & 1 & 1 & $0.03^{b}$ \\
\hline Genotype & 12 & & & & & & & & & & \\
\hline A & 3 & 3 & 2 & 1 & & & & & & & \\
\hline B & 1 & & & & & & 1 & & & & \\
\hline C & 1 & & & & & & & & & 1 & \\
\hline D & 2 & & & & 2 & & & & & & \\
\hline $\mathrm{E}$ & 5 & & 1 & 3 & 1 & & & & & & $0.02^{\mathrm{c}}$ \\
\hline $\mathrm{CHB}$ & 12 & 10 & 2 & 3 & 5 & 2 & 1 & & & 1 & $0.03^{\mathrm{b}}$ \\
\hline OBI & 77 & 51 & 19 & 16 & 16 & 26 & 11 & 3 & 5 & 7 & $0.03^{\mathrm{b}}$ \\
\hline $\mathrm{HCV}+$ & 8 & 3 & 1 & 2 & & 5 & 1 & 1 & 3 & & $0.02^{\mathrm{d}}$ \\
\hline $\mathrm{CHC}$ & 3 & & & & & 3 & 1 & & 2 & & \\
\hline Genotype & 3 & & & & & & & & & & \\
\hline 1 & & & & & & 2 & 1 & & 1 & & \\
\hline 3 & & & & & & 1 & 1 & & & & \\
\hline HIV+ & 2 & 1 & & & & 1 & & & & & \\
\hline Virological coinfection & 5 & $2(1 \mathrm{~B}, 1 \mathrm{C})$ & & & & $2(1 \mathrm{~B}, 1 \mathrm{C})$ & & & & & \\
\hline LTBI TST+ & 21 & 15 & 3 & 7 & 5 & 6 & 1 & 3 & & 2 & $0.02^{\mathrm{b}}$ \\
\hline TB \& hepatitis coinfection & 5 & 3 & 1 & 1 & 1 & 2 & & 2 & & & \\
\hline
\end{tabular}

$\mathrm{OBI}=$ anti- $\mathrm{HBC} ; \mathrm{CHB}=$ chronic active $\mathrm{HBV} ; \mathrm{LTBI}=$ latent tuberculosis infection; $\mathrm{TST}$ = tuberculin skin test.

${ }^{a}$ When the value of $P$ is not specified, the parameters compared are not statistically significant.

${ }^{b}$ Afus As.

'Evsall.

${ }^{d}$ As us Af. 


\section{Viral co-infections}

Five patients ( 3 Africans and 2 Asians) showed HBV-HCV co-infection: in 4 cases $\mathrm{HBV}$ infection was prevalent, while in 1 case HCV virus infection prevailed. Co-infection for HIV-HBV-HCV was present only in the HIV-positive African participant.

\section{Latent tuberculosis infection}

Only $82 / 238$ (34.5\%) individuals in the study population agreed to undergo the tuberculin test $(56 / 82,76.7 \%$ Africans and 24/82, 29.3\% Asians) $(P=0.02)$. Among patients tested with TST, 11 (8 Africans and 3 Asians) did not return for the control. The TST was positive (>10 $\mathrm{mm}$ ) in $21(29.6 \%)$ of the remaining 71 individuals. The prevalence of LTBI was significantly greater among Africans (71.4\%; $15 / 21)$ than among Asians $(28.6 \% ; 6 / 21)(P=0.02)$. One of the TST-positive subjects was also HIV-positive. None of the patients who were TST-positive presented radiological or microbiological signs of active pulmonary tuberculosis. All data are described in Table 2.

\section{Discussion}

The ever-increasing presence of immigrants fosters feelings of fear in the native Italian population; fear that they may introduce new and unfamiliar diseases such as SARS, MERS, Ebola, dengue, etc., or pathologies which are no longer present or have almost been eradicated from the country (11). Many of these infections may be asymptomatic for long periods and manifest themselves later in life as active diseases. This means that the incidence of certain illness may increase in host countries despite autochthonous cases declining (12).

Infection with $\mathrm{HBV}$ is prevalent in immigrants, particularly in people coming from Sub-Saharan African areas with a high rate of infection $(>8 \%)$. This figure is most likely a result of the lack of or incomplete prophylactic vaccination in the country of origin and risky sexual behaviour (13-15). In our study we evaluated the prevalence, the typology of HBV-infection and the degree of disease, based on genotype. Our findings (HBsAg positive rate: $11.2 \%$ ) reflect the current prevalent migratory flow to our geographic area, which is mostly represented by people coming from Sub-Saharan Africa. In contrast, HBV infection is rarely observed in Asian immigrants (16-18). These data, showing the differences in infection rates due to ethnicity, highlight the epidemiological pattern of the prevalence of HBV based on country of origin (13,19-21). Among our participants, more than half had $\mathrm{CHB}$, indication of a previous infection, with a clear majority from Sub-Saharan Africa (10/12 patients). The prevalence of HBV infection was similar in African children ( $<16$ years) and adults. This result leads us to postulate that the infection may occur at an early age (by vertical transmission or in childhood), in contrast with what has been observed in Western countries (17).

Most cases were infected with genotype E, which is almost exclusively disseminated in Sub-Saharan Africa
$(18,21)$. Other HBV genotypes were also found, like D, $\mathrm{B}, \mathrm{C}, \mathrm{A}$, thus reflecting different areas of origin (22-24). This redistribution of HBV genotypes represents an important change in the epidemiology of infection. In Italy, this increases the number of subjects infected with a "different" hepatitis despite the risk of reinfection with a virus of a different genotype for the Italian population being low because HBV vaccination protects from all HBV genotypes. A high proportion of patients (37.56\%) had only anti-HBc (OBI), a marker that can be indicative of either natural or artificial immunization or occult active hepatitis. This clinical situation seems to be quite frequent among individuals from Sub-Saharan Africa $(18,24)$.

Careful evaluation of OBI in the immigrant population is important because OBI can be transmitted through transfusion, organ transplantation or haemodialysis; OBI may reactivate and cause acute hepatitis in immune-compromised patients; it may contribute to the progression of hepatic fibrosis in patients with other chronic liver diseases and constitute a risk factor for hepatocellular carcinoma (25-27). Therefore, it is evident that immigrants with OBI may, if not carefully controlled, represent a risk for themselves and for the indigenous population. Currently there is no agreement on how to classify and manage individuals with OBI. Some authors suggest testing for HBV-DNA when alanine aminotransferase (ALT) levels are elevated (28), while others recommend the test only if there are other risk factors for liver disease, even with normal ALT levels $(28,29)$. We decided to check for HBV-DNA only in 5 participants who had high levels of serum ALT.

The prevalence of HCV-infection in Europe reliably indicates that about $1 \%$ of the total population is affected, albeit with regional differences (16). However, from research carried out in different countries it emerged that immigrants seem to have a very high risk of contracting $\mathrm{HCV}$-infection after their arrival in host countries (30). In Italy, the prevalence of HCV among immigrants varies with both the period and the area of research (different ethnicities), but generally it is higher than that of the local population: it ranged from $2.7 \%$ in 2008 in Verona (31) to $15.2 \%$ in 2015 in Sicily (32), with a national prevalence of 4.0-5.6\%. In this study on newly arrived immigrants the prevalence was $3.9 \%$; the patients were mainly Asians, especially Pakistani (5.3\%), while among Africans the rate was lower (2.7\%).

Such differences, as deduced from the reported risk factors, seem to be related to intravenous drug addiction, more common among the screened Asians than the Africans (9). Another risk factor was the high percentage of sexually transmitted infections (33), since all the screened HCV-positive Africans were infected via this route. An additional risk factor could have been infection via blood transfusion, blood derivative products or following invasive procedures (surgery, endoscopic tests, etc.) performed with inadequately sterilized instruments $(34,35)$. These events are not infrequent in some Asian countries, where, although public health care systems 
are accessible, they are not always at a level to prevent nosocomial infections. In contrast, in many parts of Africa, mainly in Sub-Saharan Africa, due to an almost total absence of a health care system, the possibility of carrying out invasive procedures or blood transfusions is very small. Consequently, although such a situation impedes the provision of adequate health care to people, it certainly generates comparatively lower rates of diffusion of hepatitis $C$ virus $(11,34,35)$.

Screening for HIV is systematically recommended in individuals coming from countries and communities where HIV prevalence is $\geq 0.1 \%$, such as immigrants from Sub-Saharan African and Asian countries. In fact, in these populations the risk of HIV-infection is greater than in the native population and in particular, the incidence of new HIV diagnoses in Italy is estimated to be 8 times higher in immigrants than in Italians (21). However, in our screened population, the overall prevalence of HIVinfection was $1.0 \%$, which is quite low considering that the rate of HIV-infections in the majority of the native countries of the immigrants is much higher than in Western countries, including Italy. These data confirm, after many years, previous findings from our research group that highlighted that newly arrived immigrants (<2 months) had a 1.5\% prevalence of HIV-infection (36).

This low rate could possibly be explained by the statistical bias known as the "healthy migrant effect," for which immigrants are "positively selected" from among their original population as individuals more apt to embark on such a strenuous migratory project. These migrant health advantages, however, tend to vanish over time due to high-risk behaviours. Regarding HIVinfection, the preponderance of young, sexually active males is already a risk factor, enhanced by contacts between parties belonging to the same ethnic group. Therefore, despite the high incidence of infection in immigrants resident in the country reported in previous studies, the low prevalence of HIV infection in our cohort of recently arrived individuals seems to suggest that HIVinfection is more often acquired during their stay in the host country rather than imported from the country of origin (37-39).

Active tuberculosis (TB) is an increasing problem among immigrants living in Western countries (40). It may be the clinical expression of a new infection acquired in the host country or more often the reactivation of a latent form (LTBI) brought from their country of origin $(40,41)$. Also, in Italy it has been shown that, in recent years, $>50 \%$ of new cases of TB affect immigrant subjects $(41,42)$. This LTBI represents a state of equilibrium in which the host can control the infection, but cannot completely eradicate the bacteria. This is related to a persistent immune response to stimulation by Mycobacterium tuberculosis antigens; therefore, infected individuals can be entirely asymptomatic. The greatest danger is in reactivation (active TB after remote infection) cases and the subsequent silent spread to close contacts. Therefore, patients with LTBI are the largest reservoir for potential transmission.

A high prevalence of LTBI with rates of $52-72 \%$, and elevated risk for TB reactivation with rates of $7.8 \%$, was observed in immigrants within the first 2-5 years of arrival $(43,44)$, making tuberculosis the most relevant infectious disease currently. This is predominantly among immigrants from highly endemic areas such as Sub-Saharan Africa and the Indian subcontinent. The peculiar aspect of this study is the population screened, consisting of recent immigrants residing in Italy for no longer than 3 months. Only a minority of screened immigrants $(82 / 238)$ volunteered for the TST, and 11 of those (13.4\%) did not turn up to be checked, perhaps for fear of expulsion. The prevalence of positivity for TST was of $29.6 \%$, a rate lower than what has been observed in other studies $(43,44)$. This low rate of positivity could be due to errors in the administration and reading of TST as the technique was performed "in the field" and not in a hospital setting, and subjectivity is one of the main limitations for the TST, even though it was performed by trained personnel. The presence of immunosuppression could also influence TST results, even if only a few studies are available (44). Our results were not influenced by HIVrelated immunosuppression because only 1 patient was HIV positive, with a low viral load; but other causes of immunodeficiency such as malnutrition and fatigue cannot be excluded for the most recently arrived subjects due to the hardships of their migratory journey.

\section{Conclusions}

Most immigrants are healthy people, but they can also constitute a population at risk because they might be asymptomatic carriers of infections that might be activated at a later time. It is important to determine the presence of pathologies for the immigrants themselves and for the potential public health implications. Therefore, every country that welcomes immigrants must implement affordable and cost-effective screening protocols. These programmes should be characterized by the principles of equality and respect for the immigrants, and be aimed at both the health of the individual and that of the host community. Such programmes could follow the example of Italy, where many public health facilities have voluntarily opened outpatient clinics dedicated to immigrants.

\section{Acknowledgements}

The authors are grateful to Paola Silvino and Pasquale Di Molfetta (CARA, Borgo Mezzanone, Foggia, Italy) for their kind collaboration.

\section{Funding: None.}

Competing interests: None declared. 


\section{Dépistage de maladies infectieuses chez les immigrants asymptomatiques nouvellement arrivés en Italie du Sud}

\section{Résumé}

Contexte : Le dépistage de maladies infectieuses chez les immigrants asymptomatiques est actuellement effectué lors de l'accueil de nouveaux arrivants.

Objectifs : La présente étude a pour objectif de décrire la fréquence des infections dans une cohorte d'immigrants asymptomatiques nouvellement arrivés en Italie du Sud.

Méthodes: Nous avons étudié une cohorte de 238 hommes originaires d'Afrique subsaharienne et d'Asie hébergés dans un centre d'accueil (CARA) à Foggia, entre janvier et décembre 2015. Le test cutané à la tuberculine permettant de diagnostiquer l'infection tuberculeuse latente ainsi que le test sérologique/virologique pour l'infection par le VHB, le VHC et le VIH ont été réalisés.

Résultats : Dans cette cohorte, seuls 205 individus ont accepté de se soumettre aux tests de recherche des marqueurs sérologiques/virologiques, tandis que 82 autres ont choisi de réaliser seulement le test de dépistage de l'infection tuberculeuse latente ; 49 personnes ont accepté les deux tests. Parmi les hommes ayant fait le dépistage des marqueurs virologiques, 23 sur 205 (11,2\%) étaient positifs à l'AgHBs ; 12 sur 23 (52,2\%) avaient une hépatite active chronique ; 77 sur 205 (37,6\%) étaient uniquement positifs pour l'anticorps anti-HBc. Sur les 205 individus, 8 (3,9\%) présentaient une infection par le VHC et une infection chronique par le VHC n'a été diagnostiquée que chez deux personnes. Seuls deux $(1,0 \%)$ individus sur 205 étaient positifs au test anti-VIH et à l'ARN du VIH. Une infection tuberculeuse latente a été détectée chez 29,6\% des personnes ayant effectué le test de dépistage de la tuberculose.

Conclusions : Les immigrants asymptomatiques présentent un risque accru face à certaines infections, principalement l'hépatite $C$ et la tuberculose.

$$
\begin{aligned}
& \text { فحص المهاجرين الجدد عديمي الأعر اض للتحقُق من الإصابة بالأمر اض المعدية في جنوب إيطاليا }
\end{aligned}
$$

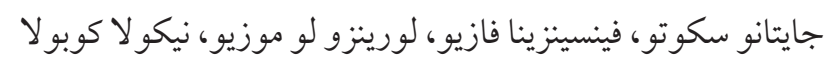

$$
\begin{aligned}
& \text { الخلاصة }
\end{aligned}
$$

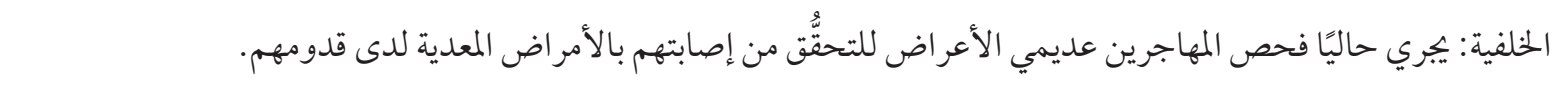

$$
\begin{aligned}
& \text { الأهداف: وصف معدل تكرار الإصابة بالعدوى لدى بجموعة من المهاجرين عديمي الأعراض القادمين حديثًا في جنوب إيطاليا. }
\end{aligned}
$$

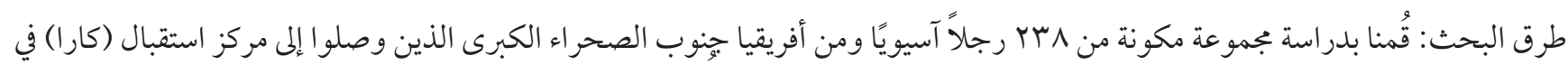

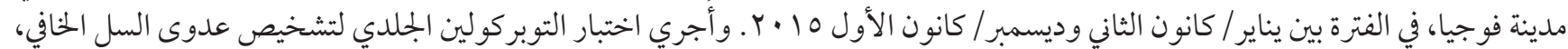

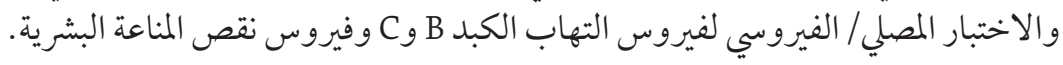

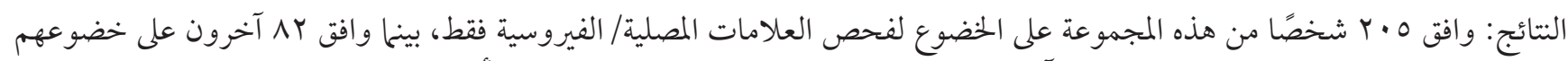

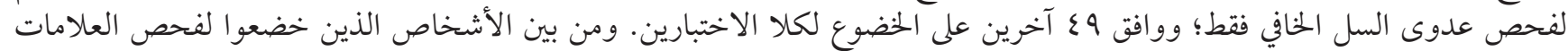

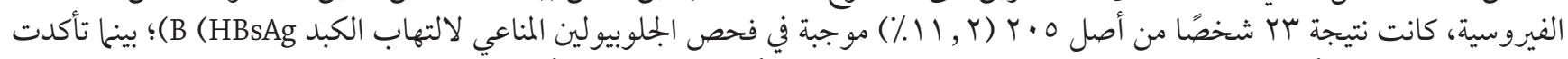

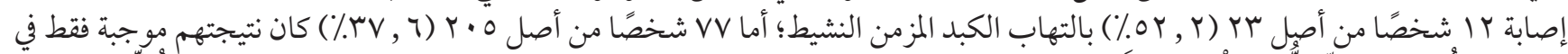

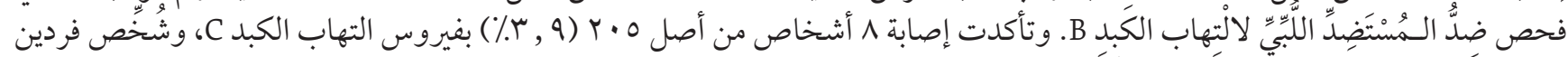

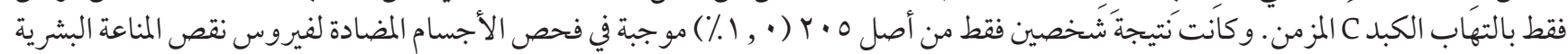

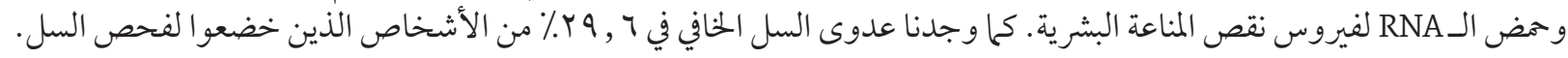

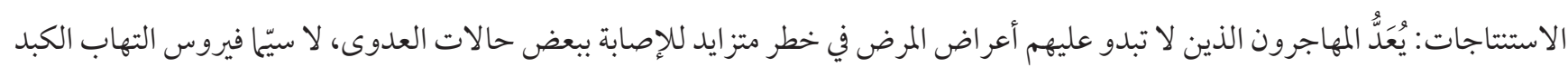

$$
\begin{aligned}
& \text { B و السل. }
\end{aligned}
$$




\section{References}

1. Migration and migrant population statistics. Brussels: European Commission, Eurostat Statistics Explained; 2017 (https://ec.europa.eu/eurostat/statistics-explained/index.php/Migration_and_migrant_population_statistics, accessed 8 January 2019).

2. Zammarchi L, Vellere I, Stella L, Bartalesi F, Strohmeyer M, Bartoloni A. Spectrum and burden of neglected tropical diseases observed in an infectious and tropical diseases unit in Florence, Italy (2000-2015). Intern Emerg Med. 2017 Jun;12(4):467-77. http:// dx.doi.org/10.1007/s11739-016-1597-1

3. Coppola N, Alessio L, Gualdieri L, Pisaturo M, Sagnelli C, Caprio N, et al. Hepatitis B virus, hepatitis C virus and himan immunodeficency virus infection in undocumented migrants and refugees in Southern Italy, January 2012 to June 2013. Euro Surveill. 2015;20(35):30009. http://dx.doi.org/10.2807/1560-7917.ES.2015.20.35.30009

4. Schepisi MS, Gualano G, Piselli P, Mazza M, D’Angelo D, Fasciani F, et al. Active tuberculosis case finding interventions among immigrants, refugees and asylum seekers in Italy. Infect Dis Rep. 2016 Jun 24;8(2):6594. DOI:10.4081/idr.2016.6594

5. Coppola N, Alessio L, Gualdieri L, Pisaturo M, Sagnelli C, Minichini C, et al. Hepatitis B virus infection in undocumentted immigrants and refugees in Southern Italy: demographic, virological and clinical features. Infect Dis Poverty. 2017 Feb 9;6(1):33. http:// dx.doi.org/10.1186/s40249-016-0228-4

6. Scotto G, Armignacco O, Starnini G, Francavilla R, Foti G, Portelli V, et al. Hepatitis C and immigration: a multicentre study. Infez Med. 2016 Sep 1;24(3):210-6. PMID:27668901

7. Dossier statistico immigrazione 2015. Rome: Centro Studi e Ricerche IDOS; 2016:1-4.

8. Barnett E. Infectious disease screening for refugees resettled in the United States. Clin Infect Dis. 2004;39:833-41. PMID:15472816

9. Observatorio permanente de la inmigracion. Madrid: Ministry of Employment and Social Security; 2014.

10. Pahissa A, Salvador F, Sanchez-Montalvá A, Bocanegra C, Molina I, Sulleiro E. Screening for imported diseases in an immigrant population: experience from a teaching hospital in Barcelona, Spain. Am J Trop Med Hyg. 2014;91(6):1277-81. DOI:10.4269/ajtmh.14-0206

11. López-Vélez R, Turrientes MC, Huerga H. Infectious disease in immigrants from the perspective of a tropical medicine referral unit. Am J Trop Med Hyg. 2003;69(1):115-21. DOI:10.4269/ajtmh.2003.69.115

12. Gushulak BD, MacPherson DW. Globalization of infectious diseases: the impact of migration. Clin Infect Dis. 2004 Jun;38(12):1742-8. PMID:15227621

13. Monge-Maillo B, López-Vélez R, Ferrere-González F, Norman FF, Martínez-Pérez Á, Pérez-Molina JA. Screening of imported infectious diseases among asymptomatic sub-Saharan African and Latin American immigrants: a public health challenge. Am J Trop Med Hyg. 2015 Apr;92(4):848-56. DOI:10.4269/ajtmh.14-0520

14. Chu JJ, Wörmann T, Popp J, Pätzelt G, Akmatov MK, Krämer A, et al. Changing epidemiology of hepatitis B and migration. A comparison of six Northern and North-Western European countries. Eur J Public Health. 2013 Aug;23(4):642-7. http://dx.doi. org/10.1093/eurpub/ckso67

15. Coppola N, Alessio L, Pisaturo M, Macera M, Sagnelli C, Zampino R, et al. Hepatitis B virus infection in immigrant populations. World J Hepatol. 2015 Dec 28;7(30):2955-61. http://dx.doi.org/10.4254/wjh.v7.i30.2955

16. Sharma S, Carballo M, Feld JJ, Janssen HL. Immigration and viral hepatitis. J Hepatol. 2015 Aug;63(2):515-22. http://dx.doi. org/10.1016/j.jhep.2015.04.026

17. Scotto G, Martinelli D, Di Tullio R, Fazio V. Epidemiological and clinical features of hepatitis B virus genotypes among immigrants in southern Italy. Hepat Res Treat. 2010; 2010:878356. DOI:10.1155/2010/878356

18. Palumbo E, Scotto G, Cibelli DC, Faleo G, Saracin A, Angarano G. Immigration and hepatitis B virus: epidemiological, clinical and therapeutic aspects. East Mediterr Health J. 2008 Jul-Aug;14(4):784-90. PMID:19166160

19. Fasano M, Saracino A, Carosi G, Mazzotta F, Marino N, Sagnelli E, et al. Hepatitis B and immigrants: a SIMIT multicenter cross-sectional study. Infection. 2013 Feb;41(1):53-9. http://dx.doi.org/10.1007/s15010-012-0384-9

20. Contini C, Badia L, Cultrera R, Grilli A, De Togni A. Epidemiological, clinical and laboratory features of chronic hepatitis B infection in a cohort of immigrant and Italian patients from Ferrara, Italy. Ann Hepatol. 2012 Nov-Dec;11(6):862-9. PMID:23109449

21. Tramuto F, Mazzucco W, Maida CM, Affronti A, Affronti M, Montalto G, et al. Serological pattern of Hepatitis B, C, and HIV infections among immigrants in Sicily: epidemiological aspects and implication on public health. J Community Health. 2012 Jun;37(3):547-53. http://dx.doi.org/10.1007/s10900-011-9477-0

22. Roca C, Balanzó X, Fernández-Roure JL, Sauca G, Savall R. Gascán J, et al. Imported diseases in African immigrants in Spain: study of 1321 patients. Med Clin (Barc). 2002;119:616-9. http://dx.doi.org/10.1016/So025-7753(02)73516-1

23. Candotti D, Opare-Sem O, Rezvan H, Sarkodie F, Allain JP. Molecular and serological characterization of hepatitis B virus in deferred Ghanaian blood donors with and without elevated alanine aminotransferase. J Viral Hepat. 2006;13(11):715-24. http:// dx.doi.org/10.1111/j.1365-2893.2006.00741.x

24. Yuen MF, Sablon E, Tanaka Y, Kato T, Mizokami M, Doutreloigne J, et al. Epidemiological study of hepatitis B virus genotypes, core promoter and pre-core mutations of chronic hepatitis B infection in Hong Kong. J Hepatol. 2004 Jul;41(1):119-25. http://dx. doi.org/10.1016/j.jhep.2004.03.004 
25. Ding X, Mizokami M, Ge X, Orito E, Iino S, Ueda R, et al. Different hepatitis B virus genotype distributions among asymptomatic carriers and patients with liver diseases in Nanning, southern China. Hepatol Res. 2002;22(1):37-44. http://dx.doi.org/10.1016/ S1386-6346(01)00120-6

26. Gibney KB, Torresi J, Lemoh C, Biggs BA. Isolated core antibody hepatitis B in sub-Saharan African immigrants. J Med Virol. 2008 Sep;80(9):1565-9. http://dx.doi.org/10.1002/jmv.21267

27. Salas J, Vázquez J, Cabezas T, Lozano AB, Cabeza I. Hepatitis B virus (HBV) infection in sub-Saharan immigrants in Almeria (Spain). Enferm Infecc Microbiol Clin. 2011;29:121-3. http://dx.doi.org/10.1016/j.eimc.2010.07.013

28. Pérez-Molina JA, Herrero-Martinez JM, Norman F, Pérez-Ayala A, Monge-Mahillo B, Navarro-Beltrá M, et al. Clinical, epidemiological characteristics and indications for liver biopsy and treatment in immigrants with chronic hepatitis B at a referral hospital in Madrid. J Viral Hepat. 2011;18(4):294-9. http://dx.doi.org/10.1111/j.1365-2893.2010.01306.x

29. Zobeiri M. Occult hepatitis B: clinical viewpoint and management. Hepat Res Treat. 2013;2013:259148. DOI:10.1155/2013/259148

30. Greenaway C, Thu Ma A, Kloda LA, Klein M, Cnossen S, Schwarzer G, et al. The seroprevalence of hepatitis C antibodies in immigrants and refugees from intermediate and high endemic countries: a systematic review and meta-analysis. PLoS One. 2015 Nov;10(11):e0141715. PMID:26558905

31. Majori S, Baldo V, Tommasi I, Malizia M, Floreani A, Monteiro G, et al. Hepatitis A, B, and C infection in a community of sub-Saharan immigrants living in Verona (Italy). J Travel Med. 2008 sept-oct;15(5):323-7. http://dx.doi.org/10.1111/j.17088305.2008.00230.x

32. Affronti M, Affronti A, Soresi M, Giannitrapani L, Campagna E, Tramuto F, et al. Distribution of liver disease in a cohort of immigrants in Sicily: analysis of day-hospital admissions in a migration medicine unit. Infez Med. 2014 Sep;22(3):200-5. PMID:25269961

33. Vriend HJ, Van Veen MG, Prins M, Urbanus AT, Boot HJ, Op De Coul EL. Hepatitis C virus prevalence in The Netherlands: migrants account for most infections. Epidemiol Infect. 2013;141(06):1310-7. http://dx.doi.org/10.1017/S0950268812001884

34. Roberts A, Kemp C. Infectious diseases of refugees and immigrants: hookworm. J Am Acad Nurse Pract. 2002;14(5):194. http:// dx.doi.org/10.1111/j.1745-7599.2002.tbool12.x

35. Scotto G, Saracino A, Pempinello R, El Hamad I, Geraci S, Palumbo E, et al. [Epidemiologic multicenter study of the prevalence of hepatitis in hospitalised immigrants in Italy in the year 2002]. Ann Ig. 2005;17(1):11-8 [in Italian]. PMID:15869166

36. Saracino A, Scotto G, Tartaglia A, Fazio V, Cibelli DC, Di Tullio R, et al. Low prevalence of HIV infection among immigrants within two months of their arrival in Italy. AIDS Patient Care STDS. 2008 Sep;22(9):691-2. http://dx.doi.org/10.1089/apc.2008.0016

37. Nicolini LA, Taramasso L, Schiavetti I, Giannini EG, Beltrame A, Feasi M, et al. Epidemiological and clinical features of hepatitis delta in HBsAg-positive patients by HIV status. Antivir Ther. 2014;20(2):193-7. http://dx.doi.org/10.3851/IMP2819

38. Stornaiuolo G, Cuniato V, Cuomo G, Nocera E, Brancaccio G, De Rosa M, et al. Active recruitment strategy in disadvantaged immigrant populations improves the identification of human immunodeficiency but not of hepatitis B or C virus infections. Dig Liver Dis. 2014 Jan;46(1):62-6. http://dx.doi.org/10.1016/j.dld.2013.08.126

39. Camoni L, Raimondo M, Regine V, Salfa MC, Suligoi B. Late presenters among persons with a new HIV diagnosis in Italy, 20102011. BMC Public Health. 2013 Mar 27;13(1):281. http://dx.doi.org/10.1186/1471-2458-13-281

40. Global tuberculosis report 2015. Geneva: World Health Organization; 2016 (WHO/HTM/TB/2015.22; http://apps.who.int/iris/ bitstream/handle/10665/191102/9789241565059_eng.pdf;jsessionid=B5911F120D7994316585EA920561721F?sequence=1, accessed 8 January 2019).

41. European Centre for Disease Prevention and Control, Tuberculosis surveillance and monitoring in Europe 2015. Stockholm: WHO Regional Office for Europe; 2015 (http://www.euro.who.int/en/health-topics/communicable-diseases/tuberculosis/publications/2015/tuberculosis-surveillance-and-monitoring-in-europe-2015, accessed 8 January 2019).

42. XXVI rapporto immigrazione 2016: nuove generazioni a confronto. Rome: Caritas Italiana; 2016 (http://szew.caritasitaliana.it/ materiali/Rapporto_immigrazione/2017/Sintesi_RICM2016.pdf, accessed 8 January 2019).

43. $\mathrm{Wu} \mathrm{J}$, Guo $\mathrm{H}$. Persistent high incidence of tuberculosis among immigrants in a low-incidence country: impact of immigrants with early or late latency. Math Biosci Eng. 2011;8(3):695-709. http://dx.doi.org/10.3934/mbe.2011.8.695

44. Choudhury IW, West CR, Ormerod LP. The outcome of a cohort of tuberculin-positive predominantly South Asian new entrants aged 16-34 to the UK: Blackburn 1989-2001. J Public Health (Oxf). 2014 Sep;36(3):390-5. http://dx.doi.org/10.1093/pubmed/fdt110 